\title{
Applying Video Learning of Media Tutorials and Actual Media Objects to Increase Student Interest and Learning Outcomes on the Clutch System Material
}

\author{
Henry Iskandar ${ }^{1}$, Dwiki Muda Yulanto ${ }^{2}$, Sapitri Januariyansah ${ }^{3}$, Siti Ulgari ${ }^{4}$, Ahmad \\ A. Sandi ${ }^{5}$ \\ Universitas Negeri Medan, Indonesia ${ }^{1234}$, \\ SMK Negeri 2 Bener Meriah, Indonesia ${ }^{5}$ \\ henryiskandar@unimed.ac.id

\begin{abstract}
This research was conducted on students of Level XI Vocational High School (SMK) of Automotive Vehicle Engineering Program. The problem faced is not found in the appropriate learning media on the material clutch system. This study aims to determine the appropriate learning media on the material clutch system to accelerate learning participation and learning outcomes. Quasy research method $2 \times 2$ factorial design experiment with samples obtained through random cluster sampling. Test analysis used descriptive statistics and two-way ANOVA analysis requirements test. The results of this study show that; (1) there are distinctions in student learning outcomes taught by using video tutorial of media learning and actual learning media, (2) there is a high impact of learning interest and low learning interest on the learning outcomes of the clutch system (3) there is an interaction between the use of teaching media and student interest in persuading the learning outcomes of the clutch system material.
\end{abstract}

Keywords: Media of Tutorial Video, Actual Media, Studying enthusiasm, Studying Outcomes, Clutch Systems.

\section{Introduction}

An educational institution's vocational school founded by the Indonesian government, namely vocational high school (SMK). The purpose of the vocational school in general to increase intelligence, knowledge, personality noble, attitude and skills to live independently and follow further education in accordance with the field of his expertise [1]. The system material clutch is one of the material lab work, which discusses powertrain/spin of a car engine, output learning which are how a knowing manner function and all that stuff components clutch, improve and care for him. The statement need device actual media and media visual packed simple in the process of learning.

The role of technology and information on learning triggers changes in the world of education [2]. The use of instructional media in the learning process in Vocational High School clutch system material has a role to improve learning outcomes cognitive and psychomotor aspects in accordance with their fields of expertise and can foster attitudes and behavior through student interest in learning. 
Using video tutorials, the teacher's role can be replaced so that the teacher can simultaneously evaluate students during the learning process [3]. Video tutorials on the learning process can be shown step by step can easily be played back and back so that the material can be more easily understood by students [4,5]. Evaluation of learning can be done when the practice learning process takes place, in the learning process of the clutch system material, namely the clutch system work process, repairing and maintenance need to need to learn over and over again practically so that it can help students correct their mistakes when doing practical learning, so that the use media of tutorial video very needed.

Vocational High Schools, laboratory facilities are a necessity as a special support for the practical learning process. Media object learning is actually also a tool that must be found in the laboratory. Because the results will know and use actual object media in the learning process aimed at being able to see and use practical tools directly students are expected to gain psychomotor when using practical tools and can form habits and increase accuracy and speed $[6,7]$.

Interest is a tendency or a great interest in something. Interest plays an important role in student life which has a major impact on attitudes and behavior. Students who are interested in creating a pleasant learning atmosphere can be supported by the use of appropriate learning media [2]. In addition to the selection of instructional media to improve learning outcomes of knowledge and skills, the most important learning process is the evidence of students' attitudes and behavior in the process [8]. Therefore the intended learning interest is asking for the learning of the teaching material of the clutch system. Learning outcomes to increase knowledge and skills, namely by learning media video tutorials and learning objects of actual objects.

The next previous research conducted showed that the instructional media for video tutorials can show increasing learning outcomes effectively [9]. To get the results of learning, cognitive and psychomotor aspects can be done by using these two media, namely video tutorial media and the actual object media in the learning process [4,10]. While the interest in learning can be grown with the use of learning media simultaneously while learning theory and practicum.

\section{Research Method}

This research was conducted on students of the XI light vehicle engineering expertise program. Determination of the characteristics of students is not grouped in the ranking or classification of superior classes, but is done random only taken a few groups of students. The sampling technique in this study was purposive random sampling. This technique was chosen because what adds to the population is the number of classes rather than the number of students in the population. The sample taken consisted of two groups, namely one class group did learning using video tutorial learning media, and another class did learning using actual object learning media.

The research method used is Quase Experiment $2 \times 2$ factorial design. The data analysis technique uses descriptive and inferential statistics by using the two-way analysis of variance analysis (ANOVA) test requirements. and the statistical test used is the F test with $\alpha=0.005$. 
Table 1. Research Design

\begin{tabular}{|c|c|c|}
\hline \multirow{2}{*}{ Variable } & \multicolumn{2}{|c|}{ Instructional Media } \\
\hline & Video tutorial media & Media of actual objects \\
\hline High Learning Interest $\left(\mathbf{X}_{\mathbf{1 . 1}}\right)$ & $\mathrm{X}_{2.1}$ & $\mathrm{X}_{2.2}$ \\
\hline Low Learning Interest $\left(\mathbf{X}_{\mathbf{1 . 2}}\right)$ & $\mathrm{X}_{2.1}$ & $\mathrm{X}_{2.2}$ \\
\hline
\end{tabular}

\section{Results and Discussion}

Table 2. Summary of Calculation Result of Descriptive Analysis

\begin{tabular}{|c|c|c|c|c|c|}
\hline \multirow{2}{*}{\multicolumn{2}{|c|}{ Summary Data }} & \multicolumn{4}{|c|}{ Use Media Learning } \\
\hline & & \multirow{2}{*}{$\begin{array}{c}\text { Statistic } \\
\mathbf{N}\end{array}$} & \multirow{2}{*}{$\begin{array}{c}\begin{array}{c}\text { Video } \\
\text { Tutorials }\end{array} \\
17 \\
\end{array}$} & \multirow{2}{*}{$\begin{array}{c}\begin{array}{c}\text { Actual } \\
\text { Objects }\end{array} \\
14 \\
\end{array}$} & \multirow{2}{*}{$\begin{array}{c}\text { Total } \\
31 \\
\end{array}$} \\
\hline \multirow{10}{*}{$\begin{array}{l}\text { Interest to } \\
\text { Learn }\end{array}$} & \multirow{5}{*}{ High } & & & & \\
\hline & & $\sum \mathbf{X}$ & 380 & 299 & 679 \\
\hline & & $\sum X 2$ & 8099 & 6477 & 14576 \\
\hline & & $\mathbf{M}$ & 22.35 & 21.36 & 43.71 \\
\hline & & $\mathbf{S 2}$ & 11.35 & 10.9 & 22.25 \\
\hline & \multirow{5}{*}{ Low } & $\mathbf{N}$ & 13 & 16 & 29 \\
\hline & & $\sum \mathbf{X}$ & 243 & 280 & 523 \\
\hline & & $\sum X 2$ & 4597 & 4942 & 9539 \\
\hline & & $\mathbf{M}$ & 18.69 & 17.5 & 36.19 \\
\hline & & S2 & 9.45 & 9.05 & 18.5 \\
\hline \multirow{5}{*}{ Total } & $\mathbf{N}$ & 30 & 30 & 30 & 60 \\
\hline & $\sum \mathbf{X}$ & 623 & 623 & 579 & 1202 \\
\hline & $\sum \times 2$ & 12696 & 12696 & 11419 & 24115 \\
\hline & $\mathbf{M}$ & 41.04 & 41.04 & 38.86 & 79.9 \\
\hline & S2 & 20.8 & 20.8 & 19.95 & 40.75 \\
\hline
\end{tabular}

Based on the descriptive analysis calculations from Table 2 above, ANOVA was calculated with a $2 \times 2$ factorial design and a summary of the results of the ANOVA $2 \times 2$ factorial design was used to test the research hypotheses in Table 3 below:

Table 3. Summary Calculation of Factorial ANOVA 2 × 2

\begin{tabular}{lcccccc}
\hline Source Varians & $\mathbf{d k}$ & $\mathbf{J K}$ & $\mathbf{R J K}$ & $\mathbf{F}_{\text {count }}$ & $\mathbf{F}$ table $\mathbf{0 , 0 5}$ & Description \\
\hline Use of media & 1 & 405.6 & 405.6 & 102.17 & 4.01 & Significant \\
\hline $\begin{array}{l}\text { Use video learning of } \\
\text { media tutorials }\end{array}$ & 1 & 383.58 & 383.58 & 96.62 & 4.01 & Significant \\
\hline $\begin{array}{l}\text { Use media of actual } \\
\text { objects }\end{array}$ & 1 & 22.02 & 22.02 & 5.55 & 4.01 & Significant \\
\hline Use of Interest to learn & 1 & 32.26 & 32.26 & 8.33 & 4.01 & Significant \\
\hline Interaction (AB) & 1 & 166.22 & 166.22 & 41.87 & 4.01 & Significant \\
\hline Error & 50 & 207.12 & 3.69 & & & \\
\hline Total & 53 & 1216.8 & & & & \\
\hline
\end{tabular}


Based on Table 3 above the summary of the $2 \times 2$ factorial design ANOVA calculation can be concluded the results of the study, that the use of video tutorial media learning and actual object learning media with learning interests that affect the learning outcomes of the clutch system material is provided by comparing the value $\mathrm{F}_{\text {count }}>\mathrm{F}_{\text {table }}$ with a significant level $\alpha 0.05$.

The results of the study stated that there were differences in student learning outcomes using instructional media video tutorial media and using object learning media actually there were differences in learning outcomes, learning outcomes using video tutorial media were higher than those taught with actual learning media evidenced by seen in Figure 1 below this:

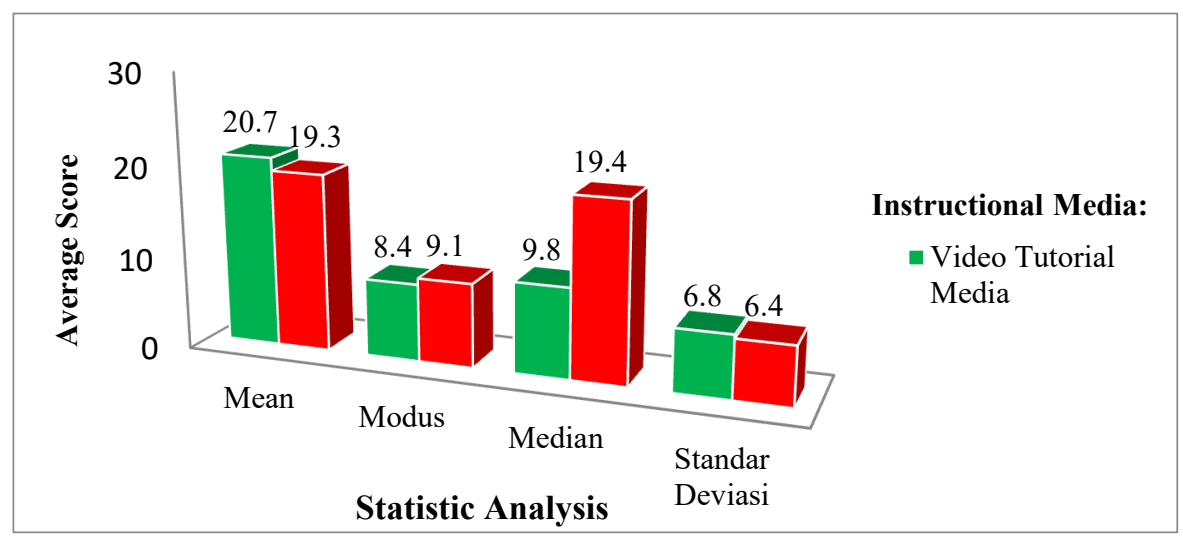

Fig 1. Graph of the average difference in learning outcomes of video tutorial media and actual media objects

The results of the research hypothesis test based on Figure 1 above can be proven that the learning outcomes using video tutorial media are higher than the actual object learning media by comparing the average score of video tutorial videos $20.7>19.03$ media objects are actually tested for truth.

The results of the study there is the influence of high learning interest and low learning interest on the learning outcomes of the clutch system material taught using video tutorial media and actual object learning media, evidenced by a comparison of average scores seen in Figure 2 below:

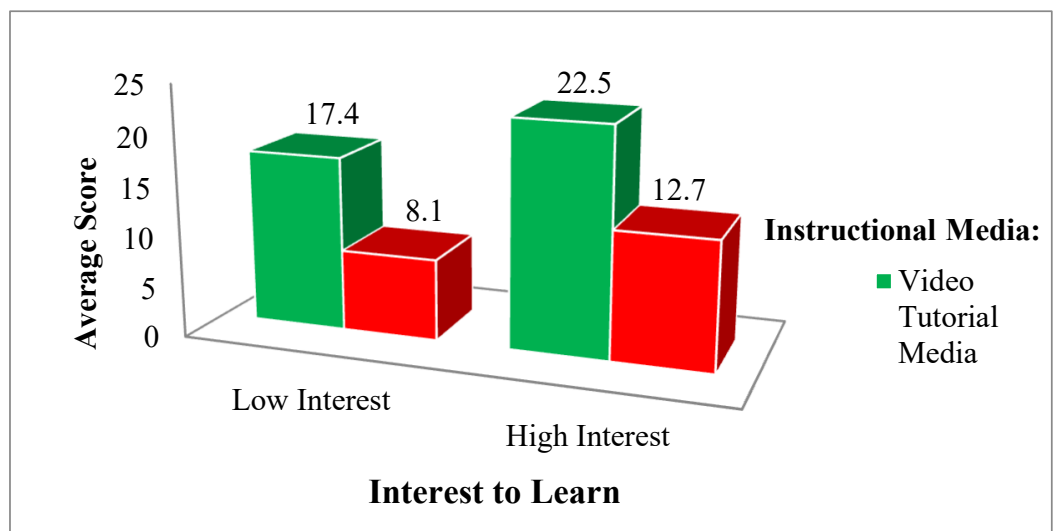

Fig 2. Graph of the average value of learning outcomes of video tutorial media and actual object media with high learning interest and low learning interest 
The results of the research hypothesis test based on Figure 2 and Table 2 above can be proven that the effect of high learning interest and low learning interest on the learning outcomes of the clutch system material is taught using video tutorial media and object learning media the value $F_{\text {count }}>F_{\text {table }} 8,33>4,01$ with a significant level $\alpha 0.05$. Then the conclusion there is a significant influence between high learning interests on the learning outcomes of the clutch system material by using truth-tested learning media.

(3) The results of the study there are interactions between the use of learning media and student interest in influencing learning outcomes of the clutch system material. The proven results of the research hypothesis test based on Table 2 above that there is an interaction between the use of instructional media and student interest in influencing the learning outcomes of the clutch system material expressed in the comparison results the value $F_{\text {count }}>F_{\text {table }}$ that is 41,87 $>4,01$ with a significant level $\alpha 0.05$. Proven comparison of the average score seen in Figure 3 below:

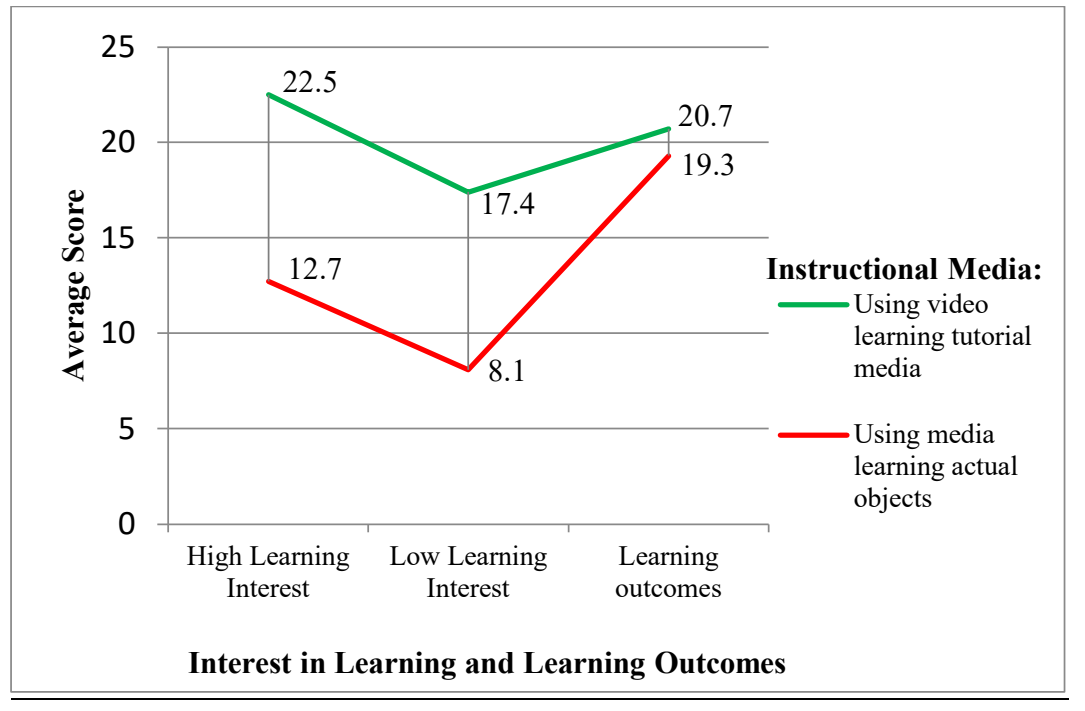

Fig 3. Line Pattern graphs of interaction using instructional media (video tutorials and actual objects) and student learning interest in learning outcomes of the clutch system material

Then the conclusion this gives an indication that the treatment of groups of students who have High Learning Interests are different from groups of students who have Low Learning Interests, meaning that one of the two groups will produce better learning outcomes when taught with Video Tutorials and other learning media would be better taught by using the Actual Objects of Learning Media.

Implementation of the use of video tutorial media learning and actual objects together will directly improve student learning outcomes on the material clutch system that has a high interest in learning. In addition, students will also be active so that they will stimulate students to move continuously to follow the steps in learning the material clutch system practicum before and when learning takes place. 


\section{Conclusion}

Based on the results of the research and discussion described earlier, it can be concluded that; (1) there is a difference in the learning outcomes of students taught using video tutorial media learning higher than using actual objects of learning media, (2) there is a high influence of learning interests and low learning interest on the learning outcomes of the clutch system taught by video learning media tutorials and actual object learning media, (3) there is an interaction between the use of instructional media video tutorials, actual object learning media and student learning interest in influencing the learning outcomes of the clutch system material.

\section{References}

[1] Bakar R. The effect of learrning motivation on students productive competencies in vocational high school, West Sumatra. Int J Asian Soc Sci. 4(6):2226-5139. http://www.aessweb.com/journals/5007. (2014)

[2] Elpira N, Ghufron A. Pengaruh Penggunaan Media Powerpoint Terhadap Minat Dan Hasil Belajar Ipa Siswa Kelas Iv Sd. J Inov Teknol Pendidik. 2(1):94-104. doi:10.21831/tp.v2i1.5207. (2015)

[3] Pendidikan S, Unesa PP. Sri Retna Pratiwi , Supari Muslim , Bambang Suprianto Abstrak. 2(2):99-106. (2014)

[4] Nuryanto J, Mesin PT, Semarang UN, Mesin PT, Semarang UN. Penerapan Media Benda Sebenarnya Untuk Meningkatkan Hasil Belajar Pada (Application Of Actual Objects Media For Increasing Learning Outcomes In Competence Basic. 18(1):29-33. (2018)

[5] Mappalotteng AM. Developing a Computer-Assisted Instruction Model for Vocational High Schools. Int J Eng Sci. 4(10):31-42. (2014)

[6] Oetopo A, Musnir DN, Yufiarti Y. Instructional development of tie dye creation for elderly using a video tutorial. IOP Conf Ser Mater Sci Eng. 434(1). doi:10.1088/1757899X/434/1/012073. (2018)

[7] Huda C, Hudha MN, Ain N, Nandiyanto ABD, Abdullah AG, Widiaty I. The Implementation of Blended Learning Using Android-Based Tutorial Video in Computer Programming Course II. IOP Conf Ser Mater Sci Eng. 288(1). doi:10.1088/1757899X/288/1/012163. (2018)

[8] Sriadhi S, Gultom S, Restu R, Simarmata J. The Effect of Tutorial Multimedia on the Transformator Learning Outcomes Based on the Students' Visual Ability. IOP Conf Ser Mater Sci Eng. 384(1). doi:10.1088/1757-899X/384/1/012059. (2018)

[9] Nurani AS, Juwaedah A, Mahmudatussa'Adah A. Video Tutorial of Continental Food. IOP Conf Ser Mater Sci Eng. 306(1). doi:10.1088/1757-899X/306/1/012006. (2018)

[10] Of D, Video T, Manufacturing FOR, Subject D, Xi OF, Vhs GOF. Pengembangan Video Tutorial Untuk Pembelajaran Gambar Development of Tutorials Video for Manufacturing Drawing Subject of Xi. (1):41-46. 